\title{
Sebuah Usaha Mencari Kasih Sayang: Kajian Semiotika dan Struktur Narasi Cerpen “Ketika Gerimis Jatuh” Karya Sapardi Djoko Damono
}

\author{
Khothibul Umam \\ Prodi Sastra Indonesia, Fakultas Ilmu Budaya, Universitas Diponegoro \\ khothibul.umam@live.undip.ac.id
}

\begin{abstract}
This study aims to examine the short story "Ketika Gerimis Jatuh" by Sapardi Djoko Damono. The method used in this research is by the approach of narrative structure and semiotics. Semiotic study with a focus on syntagmatic and paradigmatic analysis can describe the relationship of Rini, gerimis (drizzle), and his family. With a focus on syntagmatic and paradigmatic analysis can be found criticism of the modern lifestyle of parenting in children.
\end{abstract}

Keywords: semiotics, syntagmatic, paradigmatic, short story, child, family, drizzle

\section{Intisari}

Penelitian ini bertujuan untuk mengkaji cerita pendek "Ketika Gerimis Jatuh" karya Sapardi Djoko Damono. Metode yang digunakan dalam penelitian ini adalah dengan pendekatan struktur naratif dan semiotika. Kajian semiotika dengan fokus pada analisis sintagmatik dan paradigmatik dapat mendeskripsikan perihal hubungan Rini, gerimis, dan keluarganya. Dengan fokus pada analisis sintagmatik dan paradigmatik dapat ditemukan kritik terhadap gaya hidup modern perihal pengasuhan pada anak-anak.

Kata Kunci: semiotika, sintagmatik, paradigmatik, cerita pendek, anak, keluarga, gerimis

\section{Pendahuluan}

Semiotika adalah ilmu yang mengkaji tanda dalam kehidupan manusia. Artinya, semua yang hadir dalam kehidupan kita dilihat sebagai tanda, yakni sesuatu yang harus kita beri makna (Hoed, 2011: 3). Ferdinand de Saussure melihat tanda sebagai pertemuan antara bentuk (yang tercitra dalam kognisi seseorang) dan makna (yang dipahami oleh manusia pemakai makna). Ia menggunakan istilah signifiant (signifier, Ing.; penanda, 
Ind.) untuk segi bentuk suatu tanda, dan signifie (signified, Ing.; petanda, Ind.) untuk segi maknanya ${ }^{1}$.

Dalam teori de Saussure, signifiant bukanlah bunyi bahasa secara konkret, tetapi merupakan citra tentang bunyi bahasa. Dengan demikian, apa yang ada dalam kehidupan kita dilihat sebagai "bentuk" yang mempunyai "makna" tertentu. Hubungan antara bentuk dan makna tidak bersifat pribadi, tetapi sosial, yakni didasari oleh kesepakatan sosial. Karena sifatnya yang mengaitkan dua segi, penanda dan petanda, teori tanda de Saussure juga disebut bersifat dikotomis dan struktural (Hoed, 2011: 4).

Lain halnya dengan Charles Sander Pierce, ia melihat tanda sebagai "sesuatu yang mewakili sesuatu". Yang menarik adalah bahwa "sesuatu" itu dapat berupa hal yang konkret (dapat ditangkap dengan pancaindra manusia), yang kemudian melalui suatu proses, mewakili "sesuatu" yang ada dalam kognisi manusia. Jadi, yang dilihat oleh Pierce, tanda bukanlah suatu struktur, melainkan suatu proses kognitif yang berasal dari apa yang dapat ditangkap pancaindra ${ }^{2}$. Dalam teorinya, "sesuatu" yang pertamayang "konkret" - adalah suatu "perwakilan" yang disebut representamen (atau ground), sedangkan "sesuatu" yang ada di dalam kognisi disebut object. Proses hubungan dari representamen ke object disebut semiosis. Dalam pemaknaan suatu tanda, proses semiosis ini belum lengkap karena kemudian ada satu proses lagi yang merupakan lanjutan yang disebut interpretant (proses penafsiran). Jadi, secara garis besar, pemaknaan suatu tanda terjadi dalam bentuk proses semiosis dari yang konkret ke dalam kognisi manusia yang hidup bermasyarakat. Karena sifatnya yang mengaitkan tiga segi dalam suatu proses semiosis, teori semiotik Pierce disebut bersifat trikotomis $^{3}$.

Semiotika pada perkembangannya menjadi perangkat teori yang digunakan untuk mengkaji kebudayaan manusia. Roland Barthes menggunakan pengembangan teori tanda de Saussure sebagai upaya menjelaskan bagaimana kita dalam kehidupan bermasyarakat didominasi oleh konotasi ${ }^{4}$. Konotasi adalah pengembangan segi petanda oleh pemakai tanda sesuai dengan sudut pandangnya. Kalau konotasi sudah menguasai masyarakat, akan menjadi mitos (Hoed, 2011: 5).

\footnotetext{
${ }^{1}$ Lihat Ferdinand de Saussure, Course In General Linguistics (1959), hal: 65-67. Pandangan de Saussure ini kelak menjadi rujukan ahli semiotik aliran strukturalis.

2 Pandangan Pierce ini dianut oleh ahli semiotik aliran pragmatis. Lihat Benny H. Hoed, Semiotik \& Dinamika Sosial Budaya (2011), hal: 4.

${ }^{3}$ Ibid.

${ }^{4}$ Lihat Roland Barthes, Mythologies (1972), hal: 110.
} 
C.S. Pierce pun menamakan manusia sebagai homo culturalis, yakni sebagai mahluk yang selalu ingin memahami makna dari apa yang diketemukannya (meaningseeking creature) (Hoed, 2011:5). Makna dalam sejarah merupakan hasil akumulasi dari waktu ke waktu. Dengan demikian, manusia juga mencari makna dengan melihat sejarah. Dari sini sejarah bergulir ke arah mitos. Menurut Roland Barthes mitos adalah representasi kolektif yang bisa muncul dari mana saja. Mitos adalah sesuatu yang dideterminasi dari wacana sosial, ia merupakan refleksi ${ }^{5}$.

Sebagai bagian dari hasil kebudayaan manusia, sebuah teks sastra juga dipenuhi pelbagai signs. Masalahnya adalah bagaimana mengidentifikasi pelbagai signs tersebut, dan bagaimana pelbagai signs tadi tersusun dalam sebuah teks. Di sinilah semiotika sebagai ilmu tanda dapat membantu'

Kali ini akan dikaji "Ketika Gerimis Jatuh", salah satu cerpen karya Sapardi Djoko Damono yang terdapat dalam kumpulan cerita pendek Membunuh Orang Gila (2003). Sebuah cerpen yang sederhana yang dibumbui dengan beberapa narasi puitik sederhana khas Sapardi Djoko Damono.

\section{Skema Naratif Dasar "Ketika Gerimis Jatuh"}

Narasi "Ketika Gerimis Jatuh" (selanjutnya disingkat KGJ) berpusat pada tokoh Rini yang cemas menantikan ayahnya pulang kehujanan karena tidak membawa payung. Kecemasan Rini terhadap ayahnya membawanya pada suatu perasaan sepi yang memaksanya untuk menjemput ayahnya.

Skema naratif dasarnya adalah sebagai berikut:

- Rini sendiri di rumah saat gerimis jatuh sejak pagi

- Rini gelisah sambil memainkan payung

- Rini menjemput ayahnya

- Di rumah beberapa kali telepon berdering tanpa ada yang mengangkat

Dalam KGJ, Rini yang sendirian di rumah sejak pagi menjadi pusat pengisahan. Karena bosan di rumah sendiri, timbul perasaan rindu terhadap ayahnya yang belum pulang. Sebelum timbul rasa cemas, jalan cerita terlebih dahulu berkisah tentang keluarga Rini yang tinggal di sebuah Perumnas, Ibu Rini yang seorang pegawai Pemda

\footnotetext{
${ }^{5} A$ 'collective representation', can be read in the anonymous utterances of the press, advertising, mass consumer goods; it is something socially determined, a 'reflection' (Barthes, 1977:165)

${ }^{6}$ Lihat Subur L. Wardoyo, "Semiotika dan Struktur Narasi”" (2005).
} 
dan sedang rapat di Puncak, paman Rini yang seorang wartawan dan belum juga menikah.

Setelah itu, barulah adegan Rini gelisah karena hujan tidak kunjung reda. Setelah memainkan payungnya karena gelisah, barulah Rini pergi menjemput ayahnya di pinggir jalan di bawah pohon asam. Padahal di rumah, beberapa kali telepon berdering.

Dari narasi di atas, dapat kita lihat selain hujan yang menjadi pangkal masalah, kesendirian Rini juga merupakan "tanda" yang cukup penting untuk dikaji.

\section{Signifier Utama "Ketika Gerimis Jatuh"}

Dalam KGJ penulis cenderung memilih frasa "Nanti kalau ayah pulang kehujanan kasihan. Tadi lupa bawa payung" sebagai signifier utama. Hujan merupakan alasan mengapa teman-teman Rini tidak datang bermain ke rumahnya sehingga ia menjadi kesepian. Kesepian ini memicu kegelisahan Rini yang khawatir nanti ayahnya kehujanan karena lupa bawa payung. Frasa "Nanti kalau ayah pulang kehujanan kasihan. Tadi lupa bawa payung" juga diulang-ulang hingga lebih dari lima kali dengan berbagai variasi.

Ada semacam kerinduan yang sia-sia dalam kisah ini. Rini yang sudah biasa ditinggal orangtuanya pergi mendadak gelisah cuma gara-gara khawatir ayahnya kehujanan. Sosok ayah pun hanya diceritakan sekilas. Serupa bayang-bayang.

Muncul pula tafsiran lain jika sosok ayah adalah sebuah "kasih sayang" atau "teladan" yang hilang. Tentu saja kedua hal tersebut tidak dapat digantikan dengan materi apapun yang diberikan Ibu Rini kepada Rini, bahkan mainan terbaik sekalipun. Seperti yang tercantum dalam kutipan berikut:

"Tapi hari ini gerimis jatuh sejak pagi, diselingi hujan agak deras sesekali, dan gadis kecil itu sendirian saja di rumah. PR sudah selesai dikerjakannya, semua $v c d$ sudah ditontonnya, semua mainan sudah membosankannya, maka dalam kesendiriannya ia tiba-tiba merasa rindu pada ayahnya" (hal. 48).

Kebosanan yang berujung kerinduan Rini pada sosok Ayah diperparah dengan kegelisahan karena Ayah Rini tidak kunjung pulang. Sosok Ibu yang absen karena harus “dinas luar kota” juga semakin memperparah keadaan. 
"Dan sore ini gerimis, yang sesekali diselingi hujan, belum juga reda. Padahal, ibunya, yang suka menjemput ayahnya, jika kebetulan lupa membawa payung, sedang di luar kota." (hal. 49).

Ayah yang lupa membawa payung menjadi semacam peringatan bagi Rini jika ayahnya belum tentu akan datang. Kalaupun datang, Ayah pasti dalam kondisi yang tidak sehat. Mengikuti analisa di atas, lupa bawa payung adalah penyebab terhalangnya Rini mendapatkan "kasih sayang". Boleh hujan deras, asal payung jangan lupa.

\section{Analisis Sintagmatik dan Paradigmatik "Ketika Gerimis Jatuh"}

Dalam ancangan semiotika, cerpen KGJ bisa dibaca sebagai kumpulan pelbagai tanda (signs). Kemudian bagi kita sebagai pembaca tentunya ingin sekali tahu bagaimana pelbagai tanda tersebut disusun untuk membangun sebuah kerangka makna ${ }^{7}$

Untuk memenuhi rasa ingin tahu ini, kita dapat pinjam lagi teori Pierce yang mengatakan bahwa tanda-tanda diatur ke dalam kode-kode dengan dua cara, yakni dengan paradigma dan sintagma.

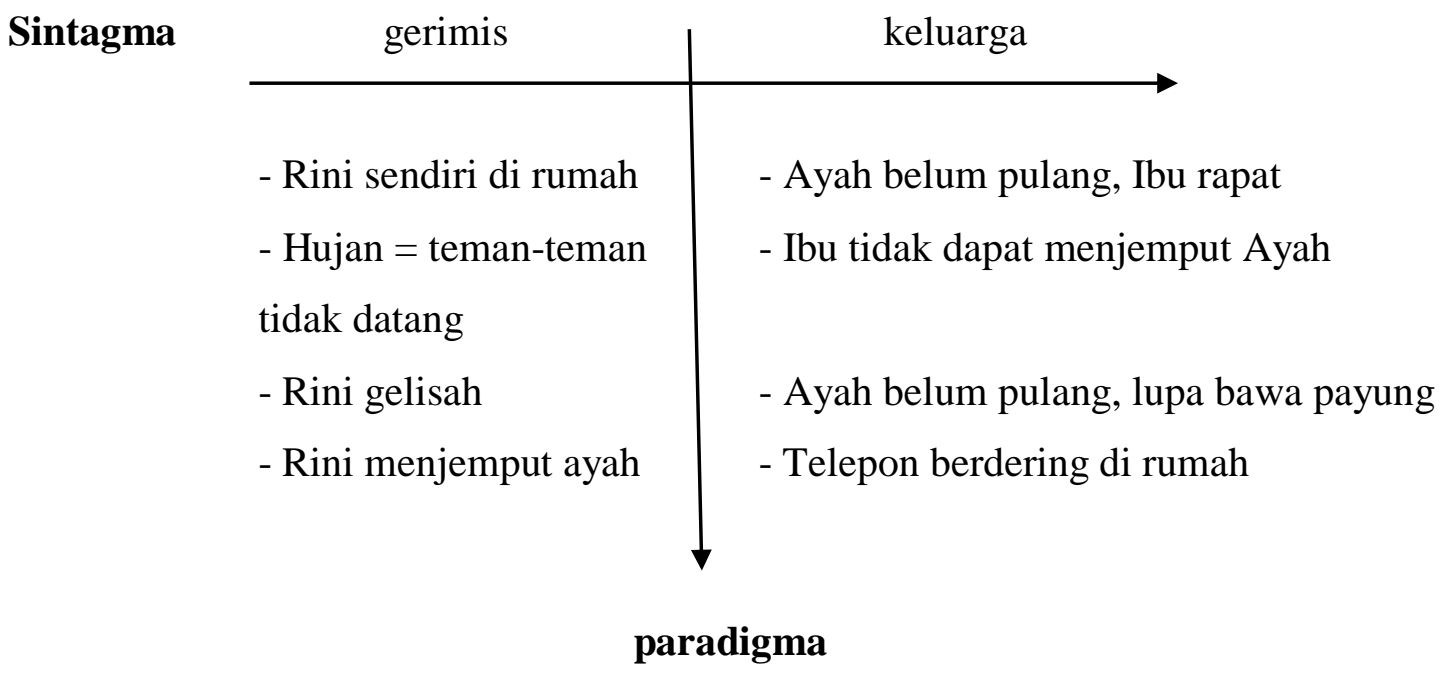

Dari kerangka aksis sintagmatik - paradigmatik di atas, kita dapat menjabarkan uraian yang menarik sekali. Dalam KGJ, Rini yang biasanya baik-baik saja ketika ditinggal kerja ayah dan ibunya tiba-tiba merasa kesepian karena teman-temannya yang biasanya main ke rumahnya urung datang karena hujan turun.

${ }^{7}$ Ibid. hal. 12. 
Kesepian Rini berubah menjadi sebuah kegelisahan ketika ia tahu ayahnya lupa membawa payung.

"Gadis itu mulai merasakan suasana sepi yang muncul dari sela-sela cahaya soreyang redup dan gerimis. Ia akhirnya berketetapan untuk menjemput ayahnya, membawakan payung untuknya. Ia tak mau melihat ayahnya selesma dan demam kalau kena gerimis senja. Ia lihat jam dinding, lalu langsung mengambil payung yang tersandar dekat pintu itu, keluar rumah setelah menutup pintu dengan hati-hati dan menguncinya. Beberapakali dicobanya handelnya. Sudah aman terkunci.” (Hal. 51).

Rini khawatir ayahnya akan terkena demam atau selesma jika terpaksa terkena hujan di sore hari. Tidak mau kegelisahan berlarut-larut, Rini mempunyai inisiatif untuk menjemput ayahnya di pinggir jalan di mana biasanya angkot berhenti.

Gerimis/hujan di sini beroposisi dengan keluarga dalam aksis sintagmatis. Keluarga di mana tempat segala kasih sayang dicurahkan kepada Rini ternyata tidak berjalan lancar dan sebagaimana mestinya. Tokoh ayah tidak muncul sama sekali, ia hanya dikisahkan oleh narasi dan muncul dalam cakapan Rini. Ibu yang seharusnya selalu ada sedang di luar kota untuk beberapa hari.

Keluarga Rini diceritakan sebagai keluarga yang tidak sempurna, meski tidak bisa dibilang keluarga yang tidak beres.

“.....Mereka bertiga keluarga yang sederhana, tidak pernah macam-macam, dan menganggap masalah keluarga sebagai ajinomoto dalam kehidupan berkeluarga...." (Hal. 50).

Semua anggota keluarga melakukan peranannya masing-masing. Sosok ayah yang tidak hadir menjadi semacam tanda pelengkap terhadap ketidaksempurnaan tersebut.

Hal tersebut diperparah dengan sebuah halangan yang bernama gerimis/hujan. Hujan sering diandaikan sebagai hal yang romantis, apalagi gerimis. Namun dalam KGJ, hujan menjadi sebuah alarm bahaya. Hujan telah membuat kehidupan Rini yang baik-baik saja meski tanpa kehadiran orang tua, menjadi sepi dan gelisah.Yang pertama tentu saja adalah ketidakhadiran teman-teman Rini di rumahnya untuk bermain bersama. Kedua adalah kelalaian Ayah Rini yang tidak membawa payung pada hari itu.

Namun ada satu hal yang harus digarisbawahi dalam KGJ, yaitu keberanian Rini untuk menjemput ayahnya ke tempat pemberhentian angkot sendirian dalam guyuran hujan. Dari narasi ini dapat kita simak jika tokoh Rini bukanlah seorang anak yang lemah. Meski ia kurang kasih sayang, ia sangat peduli pada keluarganya. 
Yang menarik, pada akhir cerita tidak disebutkan apakah Rini berhasil menjemput ayahnya atau tidak.

“......Suara cericit burung. Semakin sering dan nyaring. Gadis kecil itu mendongak, mencari-carinya di antara daunan yang rimbun dan basah. Matanya kena air, diusapnya. Seperti mengusap air mata. Angkot lewat saja. Cericit burung. Gadis itu mendongak lagi, mengusap lagi matanya yang kena air. Suara azan maghrib.

Di rumah, beberapa kali telepon berdering." (Hal. 53).

Cuplikan di atas menjadi akhir cerita yang menarik, apalagi ditambah dengan telepon rumah yang terus berdering dengan tanpa diketahui oleh Rini. Pada titik ini, antara Rini dan orang tuanya tidak bertemu sama sekali. Kita pun tidak tahu sampai kapan Rini menunggu ayahnya atau siapa yang menelpon rumah Rini.

Pandangan akhir tentang Rini adalah seorang tokoh yang terlihat lemah dan kurang kasih sayang, namun berani berjuang untuk orang-orang yang disayanginya, untuk keluarganya. Sangat klise memang. Namun dengan akhir cerita seperti di atas, pembacalah yang nanti menentukan nasib atas Rini.

\section{Ayah yang Lupa Membawa Payung dan Hilangnya Kasih Sayang Orangtua}

Dalam KGJ peran orangtua sangatlah vital. Kedua orangtua Rini adalah orangtua modern, di mana keduanya adalah suami istri karir. Meskipun sangatlah sibuk, kedua orangtua Rini selalu berusaha mengganti waktu yang hilang dengan Rini dengan berbagai materi, terutama mainan.

Hilangnya waktu pengasuhan terhadap anak adalah sebuah keniscayaan dalam masyarakat modern. Dalam masyarakat modern sektor publik tidak hanya didominasi kaum pria. Kaum perempuan juga banyak berkarir. Konsekuensinya adalah jika sebelumnya masalah pengasuhan anak dibebankan pada kaum perempuan atau ibu, maka kondisi sekarang sudah sangat berbeda.

Hal ini berkaitan dengan peran perempuan sebagai seorang ibu yang pada mulanya berfungsi sebagai pengasuh bagi anak-anaknya, sekarang ikut terjun langsung ke sektor publik. Tanggung jawab yang bertambah tadi tentu saja memakan korban ${ }^{8}$.

Tokoh Rini mempunyai beberapa masalah. Awalnya ia merasa baik-baik saja meskipun kedua orangtunya sangatlah sibuk. Substitusi kasih sayang berupa mainan sudah sangatlah cukup mengganti. Namun semuanya berubah ketika hujan datang dan

\footnotetext{
${ }^{8}$ Lihat Yuki Widiasari dan Desti Pujiati, "Pengasuhan Anak Usia Dini bagi Orang Tua Pekerja” (2017).
} 
tokoh Ayah tidak membawa payung serta Ibu sedang dinas ke luar kota. Kondisi tersebut merupakan kondisi yang luar biasa, yang sebelumya tidak pernah terjadi.

Sapardi Djoko Damono mencoba melemparkan kritik yang bernas dengan simbol hujan. Hujan dalam KGJ merupakan sebuah ancaman yang nyata, sebuah sebab kasih sayang yang hilang. Secara lebih mendalam, sosok Ayah yang dirindukan betulbetul tidak hadir di sini.

Dampak Ayah yang absen (fatherless) adalah munculnya kecemasan bagi anak. Performa perilaku anak sangat dipengaruhi oleh kehadiran seorang ayah. Lebih lanjut hilangnya sosok ayah dapat mengakibatkan depresi, perilaku menyimpang, menurunkan performa akademik, rendah diri, mudah marah, dan rendahnya kontrol diri ${ }^{9}$.

Sosok Ibu yang sebelumnya bisa menjadi pengganti sosok Ayah juga tidak dapat hadir. Akhirnya Rini pun berusaha mencari "kasih sayang" dengan caranya sendiri. Ia berani menerobos hujan untuk membawakan payung bagi ayahnya.

"Burung kecil itu bercericit lagi. Kasihan. Mungkin ia belum makan. Ibunya ke mana? Beberapa angkot lewat, terus saja tidak ada yang turun. Kasihan Ayah. Kenapa lupa bawa payung, Yah? Ayah mestinya tidak usah bingung, dong, kalau Ibu nggak nelpon." (hal. 52-53).

\section{Simpulan}

Kasih sayang berhak didapatkan oleh setiap anak dan tugas seluruh orang tua untuk memberikannya. "Ketika Gerimis Jatuh" secara halus menyindir tentang gaya hidup modern, di mana kedua orang tua sangat sibuk bekerja sehingga kasih sayang terhadap anak terabaikan. Memang ada kasih sayang "pengganti” berupa mainan yang bagus dan melimpah, namun semua itu tidaklah cukup mengganti peran kasih sayang yang sebenarnya.

Rini yang sadar dengan kondisi keluarganya mencoba memahami mengapa orang tuanya jarang ada di rumah. Pada titik tertentu, sang anak akan keluar dari rumah untuk mencari kasih sayang yang tidak kunjung diberikan oleh orang tuanya.

Kondisi hilangnya kasih sayang pasti sangat berpengaruh terhadap proses tumbuh kembang anak. Bagaimanapun yang ideal adalah keluarga yang utuh dengan kasih sayang yang cukup. Kasih sayang orang tua tidak akan pernah tergantikan, bahkan dengan materi sebesar apapun.

\footnotetext{
${ }^{9}$ Lihat Susanto, "Menjadi Orangtua Hebat di Era Kini", 2016.
} 


\section{Daftar Pustaka}

Barthes, Roland. 1972. Mythologies. New York: The Noonday Press. 1977. Image, Music, Text. London: Fontana Press.

Damono, Sapardi Djoko. 2003. "Ketika Gerimis Jatuh”, dalam Membunuh Orang Gila. Jakarta: Penerbit Buku Kompas.

Hoed, Benny H. 2011. Semiotik \& Dinamika Sosial Budaya (Edisi Kedua). Depok: Komunitas Bambu.

Saussure, Ferdinand de. 1959. Course In General Linguistics. New York: Philosophical Library.

Susanto. 2016. "Menjadi Orangtua Hebat di Era Kini”, dalam Detik. Pranala: https://news.detik.com/kolom/3245161/menjadi-orangtua-hebat-di-era-kini, dilihat Minggu, 24 Juli 2018, pukul 13.15 WIB.

Wardoyo, Subur L. 2005. "Semiotika dan Struktur Narasi”, dalam Kajian Sastra, Vol. 29, No.1 (Januari).

Widiasari, Yuki dan Desti Pujiati. 2017. "Pengasuhan Anak Usia Dini bagi Orang Tua Pekerja", dalam Jurnal Indria, Vol 2, No. 2 (September). Pranala: https://www.researchgate.net/publication/319936992_PENGASUHAN_ANAK USIA_DINI_BAGI_ORANG_TUA_PEKERJA, dilihat Minggu, 24 Juli 2018, pukul 12.55 WIB. 